\title{
G. ROBERT CROWNINGSHIELD: A LEGENDARY GEMOLOGIST
}

Thomas M. Moses and James E. Shigley

During his more than 50 years of involvement with the GIA Gem Laboratory, G. Robert (Bob) Crowningshield has made many significant contributions to the study of gems and the science of gemology. These include fundamental advances in the understanding and identification of treated and synthetic diamonds; of colored stones such as tanzanite, amethyst, "padparadscha" sapphire, and heat-treated corundum; and of natural and cultured pearls. In the early 1950s, Crowningshield demonstrated the value of new equipment in gem testing, in particular the spectroscope. He also helped develop and teach the GIA diamond grading system, now the standard worldwide. Along the way, he shared his wealth of practical experience in hundreds of articles, lectures, and industry presentations. All of these achievements helped lay the foundation of modern gemological research.

M uch of gemology as we know it today can be traced to the work of just a few individuals, mainly in Europe and the United States, who pioneered the modern study of gem materials in the 1930s, '40s, and '50s. This group includes G. F. Herbert Smith, Robert Shipley, Robert Shipley Jr., Basil Anderson, Dr. Edward Gübelin, Prof. Karl Schlossmacher, Richard Liddicoat, Robert Webster, Lester Benson, Prof. Hermann Bank, and Alan Jobbins. Their work involved not only the examination and classification of natural gems, but also the expanding study of treated, synthetic, and imitation gem materials, and the development of new methods and equipment for gem identification and quality grading. Prominent in this small group is G. Robert Crowningshield (figure 1), who joined GIA in 1947 and subsequently became one of the original staff members of the GIA Gem Trade Laboratory, which was formally established in 1949.

October 29, 2002, marked Crowningshield's 55 th anniversary with the Institute. In the course of his laboratory career, he arguably tested more colored stones and pearls and analyzed more diamonds than anyone else during that period.
Throughout his tenure in the laboratory, he has brought keen observational and analytical skills, as well as a phenomenal memory, to the identification of a broad variety of gem materials. He has shared the results of his work with thousands of GIA students and members of the trade through his presentations and published articles. Since 1958, he has co-authored (and served as contributing editor for) the popular "Lab Notes" section of Gems \&) Gemology, where in more than 1,000 entries he reported on interesting items encountered in the GIA laboratory. As a tribute by colleagues who have been fortunate to work alongside him, the present article highlights some of Crowningshield's many contributions to gemology, and provides a bibliography of his published articles, to which readers are directed for information on the many discoveries and developments discussed below.

\footnotetext{
See end of article for About the Authors and Acknowledgments. GeMS \& GemOlogy, Vol. 38, No. 3, pp. 184-199.

(C) 2003 Gemological Institute of America
} 
Figure 1. For more than 50 years, G. Robert

Crowningshield has devoted his life to the study of gems and shar-

ing this information with members of the jewelry industry. During this time, he has made important contributions to gem identification and grading, instrument development, and gemological education. Photo by Howard Wechsler, (C) GIA.

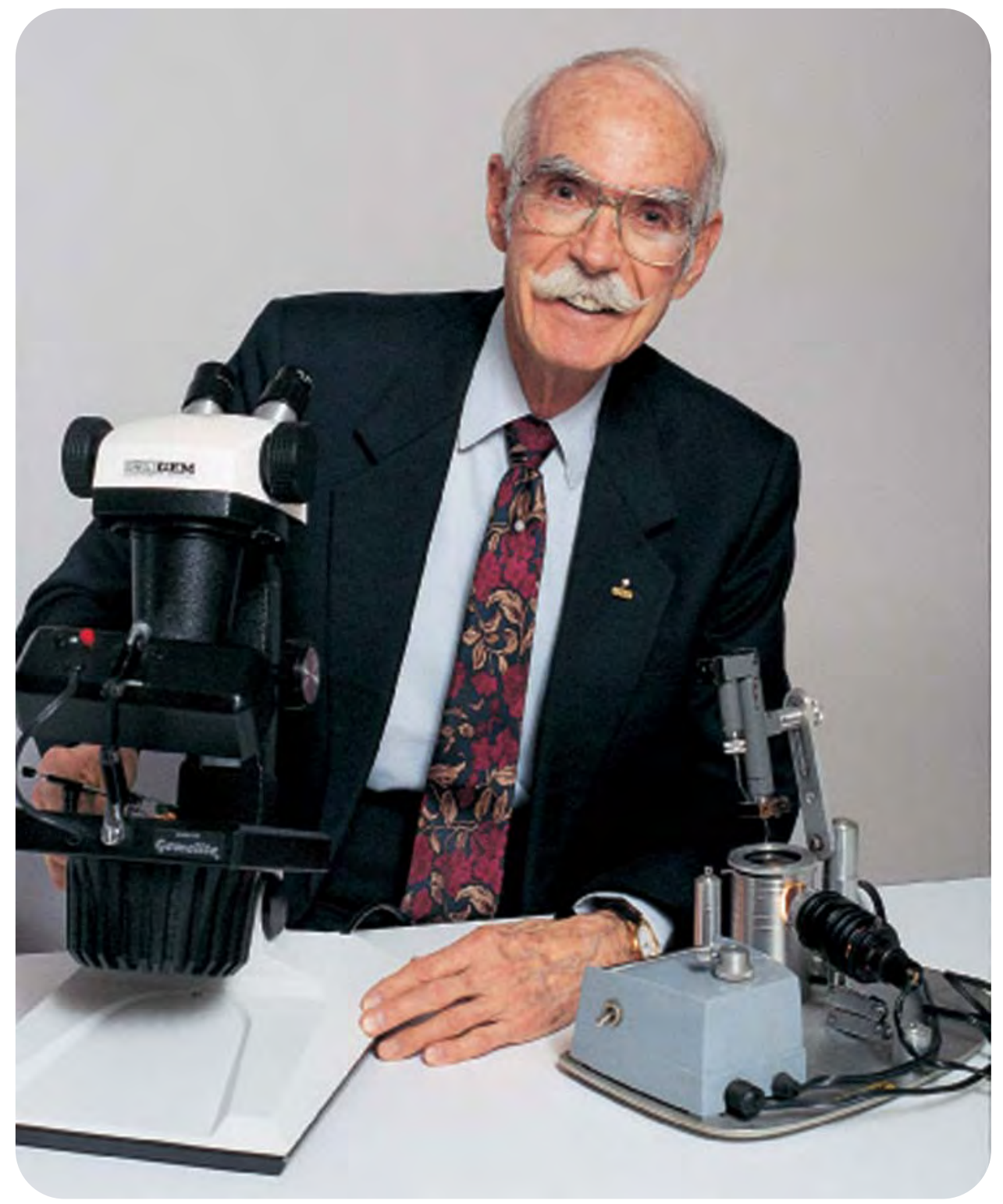

\section{BACKGROUND}

George Robert (Bob) Crowningshield was born on June 16, 1919, in Colorado Springs, Colorado. In 1927, his parents moved Bob and his three siblings to San Diego, California, where an early interest in gemstones was further sparked by visits to the famous gem pegmatites in San Diego County. He attended high school in Spring Valley, California, and in 1942 received a Bachelor of Arts degree in natural science from San Diego State College (now San Diego State University). There, he also developed an interest in drawing as a "way to train myself to pay close attention to things." He would later put this skill to great use in his gemological career.

During World War II, from 1942 to 1945, Crowningshield served with the U.S. Navy. As a way to pass long hours at sea, he read books on gemstones. He began purchasing gems during port visits to Australia, India, and Ceylon (now Sri Lanka), and even designed gold settings for the gems that he and others had bought. Toward the end of the war, a chance encounter during one of these port visits led him to the Gemological Institute of America.

Crowningshield's budding interest had made him the ship's unofficial authority on gems, an adviser to shipmates who went shopping for stones when in port. One of these was the ship's captain, who needed a gift to take home to his wife (figure 2). Crowningshield, the ship's navigator, suggested an unscheduled stop in Ceylon to purchase some star sapphires. When the ship pulled into the port of Colombo- "the captain told [the Navy] we were 
examine tens of thousands of gemstones of all kinds. In fact, only a little more than 10 years after the East Coast laboratory was formed, its staff members were examining over 100,000 diamonds, colored stones, and pearls annually (see "The new Eastern headquarters. . . ," 1960). Passionate about the mysteries that surrounded natural, treated, and synthetic gem materials, Crowningshield embraced gemological research as an important component of laboratory work, and in the process made a number of important contributions to gemology.

\section{MASTER OF THE SPECTROSCOPE}

Although Crowningshield was as astute in the use of the gemological microscope as any of the world's most renowned gemologists (figure 4), perhaps the most significant advance associated with him is the use of the spectroscope in gem identification (again, see figure 1). Although not the first to see its potential in gemology, he was arguably the most successful in applying it to this new science, sharing the information it provided with the gemological community.

One day in 1950, Crowningshield and his colleague Bert Krashes were trying, unsuccessfully, to master a recently acquired Beck diffraction-grating spectroscope when Hans Myhre-a Norwegian gemologist and wholesale jeweler-stopped by. Recognizing their dilemma, Myhre placed a garnet in front of the instrument and calmly showed them how to view the spectrum. Crowningshield was fascinated, and within a short time he became one of the masters of the spectroscope for gem identification. Just as important, he made it his mission to record the spectrum of every gem variety that came through the lab-using a stencil, charcoal dust, cotton swabs, erasers, a cotton rag, and pencils to mimic the subtle spectral features he saw in the instrument. Through months of painstaking work, often on weekends when the building housing the laboratory was unheated, he created a collection of realistic, hand-drawn spectra of a wide variety of gemstones. He recorded them in a notebook along with other properties of the gem, so he could make correlations. This ability to make correlations and, as a result, new discoveries, was one of Crowningshield's greatest assets as a gemologist.

His collection of drawings, one of the earliest databases of the visible spectra of gem materials, was first published as 114 black-and-white plates in the sixth edition (1962) of Richard T. Liddicoat's Handbook of Gem Identification (see, e.g., figure 5). Crowningshield documented nearly every transpar-

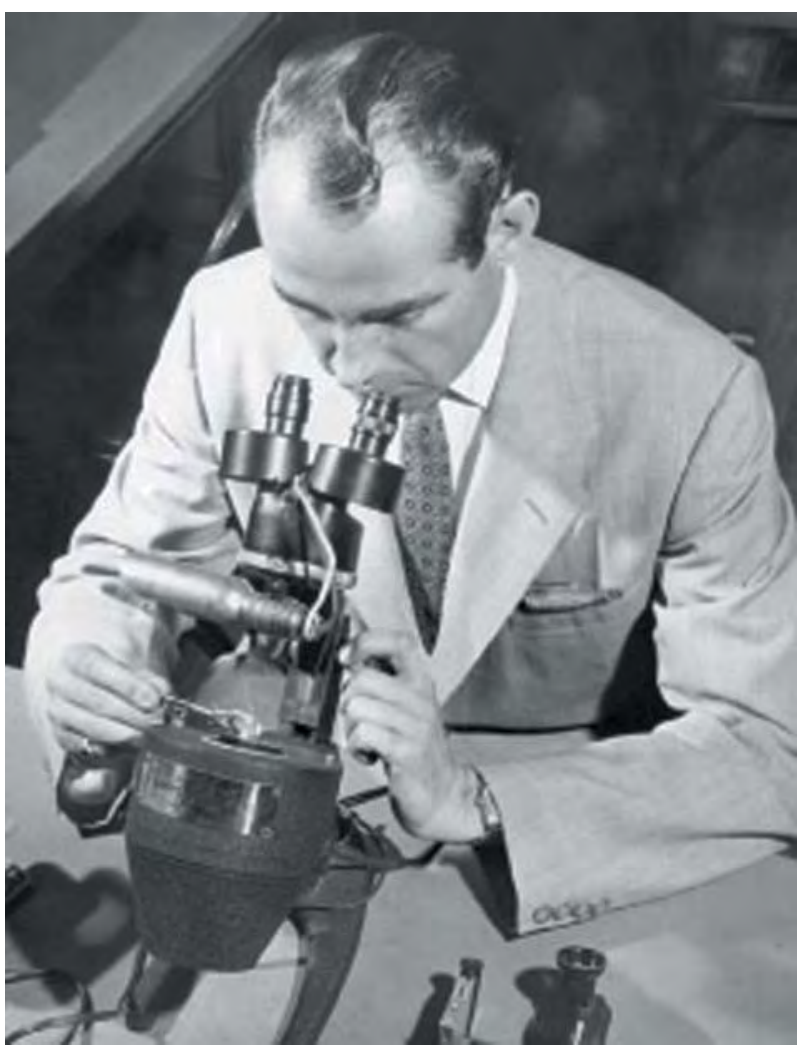

Figure 4. During his several decades in the laboratory, Bob Crowningshield used the microscope for many of his discoveries. This photograph, taken in the 1950s, shows him using an early-version Diamondscope, a binocular gemological microscope with lightfield and darkfield illumination that had been developed by GIA in the 1930s and '40s.

ent colored stone he had studied in the laboratory. These illustrations in Liddicoat's widely used textbook, combined with an earlier description that Crowningshield wrote in a 1957 Gems 4 Gemology article (in which he also included examples of his spectra), made the spectroscope a more practical gem identification tool for trained gemologists. In less than 10 years, largely as a result of his efforts, the spectroscope went from a rarely used specialist's instrument to one of the practicing gemologist's most important gem identification tools. And it would prove essential to the development that cemented both Crowningshield's reputation and that of the Gem Trade Laboratory.

\section{A WIZARD IN GEM IDENTIFICATION}

The Clue to Color Origin in Yellow Diamonds. Beginning in the early 1950s, commercial amounts of irradiated colored diamonds began to appear in the 
U.S. market. It became critically important to develop new methods to detect these treated diamonds, which had been irradiated by nuclear bombardment from radioactive materials (mainly radium bromide) or by exposure to radiation in a cyclotron or a nuclear reactor (figure 6). Gemologists had already learned that the so-called radium-treated diamonds could be detected by their autoexposure of photographic film due to residual radioactivity ("Radium-treated diamonds," 1938), whereas most cyclotron-treated diamonds exhibited facet-related color zoning that was visible with magnification (Pough and Schulke, 1951). However, diamonds irradiated in a reactor (and then possibly heat treated to produce additional changes in color) did not leave any signature on photographic film, and displayed even coloration when examined with a loupe or microscope: This treatment appeared to be undetectable. Concerned jewelers and diamond dealers pressured GIA to find a means of identification, but the laboratory staff had little success until a watershed event in January 1956.

That month, the laboratory was asked to determine the origin of color of a 19 ct yellow diamond. "It was the biggest one we had ever seen," Crowningshield said later, "and it offered the best opportunity to see if there was something about this diamond's color that was due to treatment" (Shuster, 2003).

Figure 5. Shown here are two of the spectra Crowningshield provided for the sixth edition of Liddicoat's Handbook of Gem Identification, published in 1962. The top spectrum is of an irradiated and annealed yellow diamond (with a $5920 \AA$ [592 nm] line); the bottom one is of an untreated yellow diamond (with a Cape spectrum, lines at 4150, 4530, and $4780 \AA$ ).
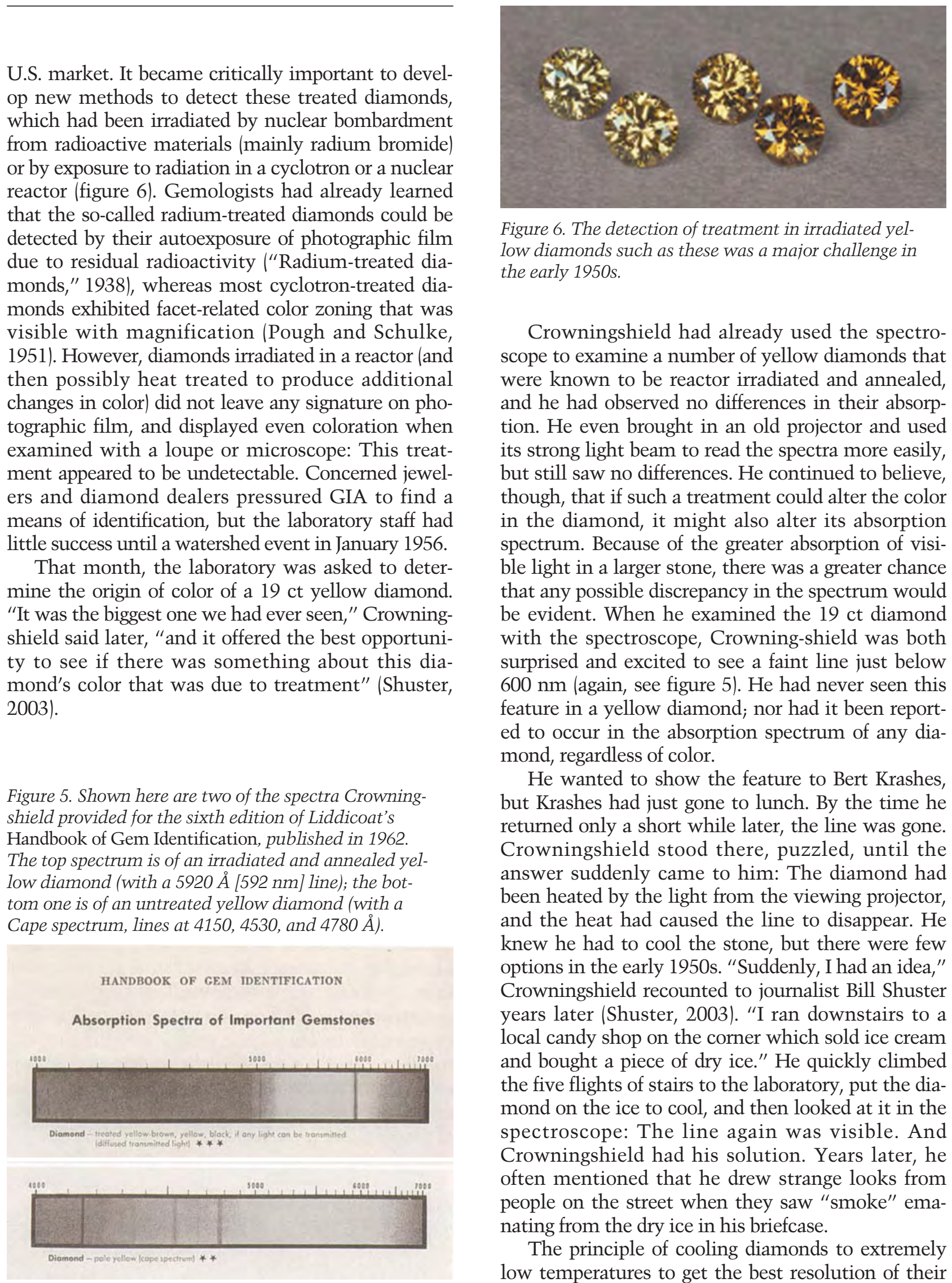

Figure 6. The detection of treatment in irradiated yellow diamonds such as these was a major challenge in the early 1950s.

Crowningshield had already used the spectroscope to examine a number of yellow diamonds that were known to be reactor irradiated and annealed, and he had observed no differences in their absorption. He even brought in an old projector and used its strong light beam to read the spectra more easily, but still saw no differences. He continued to believe, though, that if such a treatment could alter the color in the diamond, it might also alter its absorption spectrum. Because of the greater absorption of visible light in a larger stone, there was a greater chance that any possible discrepancy in the spectrum would be evident. When he examined the 19 ct diamond with the spectroscope, Crowning-shield was both surprised and excited to see a faint line just below $600 \mathrm{~nm}$ (again, see figure 5). He had never seen this feature in a yellow diamond; nor had it been reported to occur in the absorption spectrum of any diamond, regardless of color.

He wanted to show the feature to Bert Krashes, but Krashes had just gone to lunch. By the time he returned only a short while later, the line was gone. Crowningshield stood there, puzzled, until the answer suddenly came to him: The diamond had been heated by the light from the viewing projector, and the heat had caused the line to disappear. He knew he had to cool the stone, but there were few options in the early 1950s. "Suddenly, I had an idea," Crowningshield recounted to journalist Bill Shuster years later (Shuster, 2003). "I ran downstairs to a local candy shop on the corner which sold ice cream and bought a piece of dry ice." He quickly climbed the five flights of stairs to the laboratory, put the diamond on the ice to cool, and then looked at it in the spectroscope: The line again was visible. And Crowningshield had his solution. Years later, he often mentioned that he drew strange looks from people on the street when they saw "smoke" emanating from the dry ice in his briefcase.

The principle of cooling diamonds to extremely low temperatures to get the best resolution of their 
spectra is still used by gemologists today, albeit with more sophisticated techniques.

Crowningshield knew, however, that nothing could be proved by a single observation in a single stone, so he returned the diamond to the client with a statement to the effect that the origin of the color was "undetermined" — and immediately embarked on a landmark study of the absorption spectra in natural and irradiated yellow diamonds. "Before we announced anything," he said later, "we had to be sure that what we had was foolproof" (Shuster, 2003).

Over a period of about 10 months, Crowningshield and his colleagues set out to obtain as many known natural- and treated-color yellow diamonds as possible. It was the most intensive test of a theory ever attempted in gemology to this point, and it helped to institute the rigorous analysis common in contemporary gemological research (Shuster, 2003). To this end, New York diamond dealer Theodore Moed loaned his entire stock of known treated and untreated diamonds for examination. Additional diamonds that were unequivocally natural color were found in the collections of the American Museum of Natural History and Tiffany \& Co., among others. Also tested were hundreds of pieces of non-gem yellow rough that was so inappropriate for the jewelry industry that treatment was extremely unlikely.

Ultimately, Crowningshield and his colleagues examined the spectra of more than 10,000 yellow diamonds. His studies, which were published in the Winter 1957-1958 issue of Gems « Gemology, confirmed that the absorption line at $5920 \AA(592 \mathrm{~nm}$, later redesignated to occur at $595 \mathrm{~nm}$ when the spectra were recorded with a spectrophotometer) was indeed a diagnostic feature of laboratory-irradiated and annealed yellow diamonds. The trade was ecstatic, and soon it became essential for any yellow diamond of significance to have a laboratory report. More importantly, perhaps, wrote Modern Jeweler's David Federman almost 40 years later $(1995$, p. 26), this discovery "elevate[d] gemology from an academic pursuit to a key means of strategic defense in the jewelry industry. Seen in this way, 592 didn't just mark a point on the spectrum. It marked a turning point in the history of gemology."

Early Work in Colored Stones and Pearls. Crowningshield also pioneered other methods of gem examination and identification. Using a procedure initially developed by fellow staff member Lester Benson (1948), he refined a method for measuring the R.I. of cabochon-cut gems that he described in a $1949 \mathrm{Get} G$

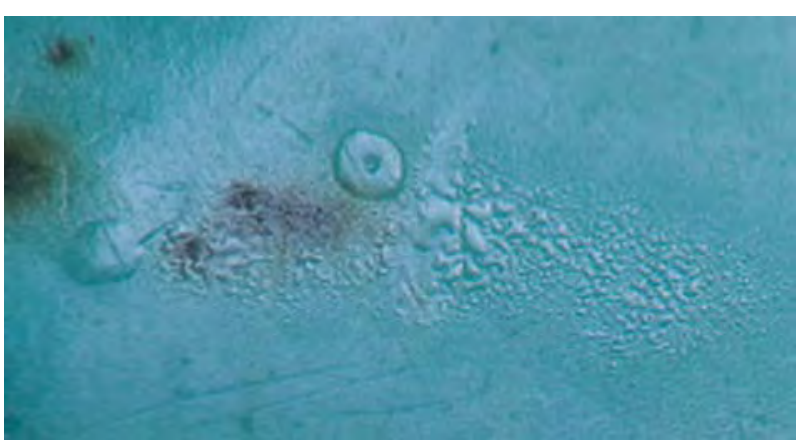

Figure 7. Crowningshield provided one of the earliest reports on the "sweating" of wax-treated turquoise when exposed to a hot point in a 1959 "Highlights at the Gem Trade Lab in New York," a precursor to today's Lab Notes section. Photomicrograph by Shane F. McClure; magnified 23x.

article. In 1951, decades before it became more popularized by Alan Hodgkinson (1995), Crowningshield pioneered the development of simple visual techniques to determine important optical properties by holding the gem close to the eye and looking through the table facet. As we can attest, it is amazing to actually resolve an optic figure of a gemstone using your eye as the condensing lens.

Between 1958 and 1960, Crowningshield investigated a wide variety of treated and synthetic gem materials. His discoveries and observations (e.g., as published in the "Lab Notes" listed in table 1 and his bibliography) included: the "sweating" reaction of wax-treated turquoise to a hot point (figure 7), the recognition of sugar-acid treatment of porous opal, spectroscopic studies of diamonds and their origin of color, the identification of synthetic rutile (a diamond simulant), and a study of flux-grown synthetic emerald.

The laboratory that GIA acquired in the fall of 1949 had been set up in 1940 primarily for testing pearls, and Bob Crowningshield continued its tradition of pearl research throughout his long career. As early as 1951, he participated in the development and installation of a new X-ray system, which was optimized for taking radiographs of the internal structure of natural and cultured pearls (figure 8; see Benson, 1951-1952). In 1961, Crowningshield reported on natural-color black pearls, to confirm by visual and spectroscopic methods that they had not been treated (also see Benson, 1960). A little over a decade later, in the mid-1970s, cultured black pearls were beginning to be produced in Tahiti (figure 9), but there was widespread doubt in the trade that their color was natural. Pearl dealer Salvador Assael supplied Crowningshield with hundreds of the new cultured 
TABLE 1. Selected entries from the "Lab Notes" column by G. R. Crowningshield.

\begin{tabular}{|c|c|c|c|c|c|}
\hline Entry & Comments & Vol. & No. & Issue $^{2}$ & Page(s) \\
\hline Treated yellow, red, green diamonds & Increasing numbers submitted for identification & 9 & 9 & Sp 1959 & 268 \\
\hline Imitations for jade & Increasing variety of examples seen in the trade & 9 & 9 & Sp 1959 & 269 \\
\hline Natural-color blue diamonds & Electrical conductivity tester designed and built & 9 & 10 & Su 1959 & 291 \\
\hline Cream-rosé baroque pearls & Freshwater cultured pearls from Lake Biwa, Japan & 9 & 10 & Su 1959 & 292 \\
\hline Coated diamond & Coating substance detected on pavilion surface only & 9 & 10 & Su 1959 & $292-293$ \\
\hline Brownish yellow diamond & Green in daylight, reverts to brownish yellow in dark & 9 & 10 & Su 1959 & 293 \\
\hline Pink diamond & Turns brown to X-rays; reverts to pink with gentle heating & 9 & 12 & W 1959-1960 & 360 \\
\hline Cultured pearls with pink dye & Pink dye stains visible in drill hole and on silk thread & 9 & 12 & W 1959-1960 & 361 \\
\hline Treated blue diamonds & Originally light brown and off-color based on spectra & 9 & 12 & W 1959-1960 & 361,377 \\
\hline Hope diamond & Testing at Smithsonian with new conductivity tester & 10 & 1 & Sp 1960 & 10 \\
\hline Synthetic emerald & First time seen with visible platinum inclusions & 10 & 2 & Su 1960 & 61 \\
\hline Radium-treated diamonds & Green color; autoradiograph produced on X-ray film & 10 & 8 & W 1961-1962 & 242 \\
\hline Diamond doublets in jewelry & Diamonds mounted with synthetic sapphire or spinel backs & 10 & 10 & Su 1962 & $305-306$ \\
\hline Turquoise imitations & Reconstituted by compression of components & 10 & 11 & F 1962 & 336 \\
\hline Gray type Illb diamond & Electrically conductive, blue UV phosphorescence & 10 & 11 & F 1962 & 341 \\
\hline Cyclotron-irradiated diamond & Unusual pale green with a facet-related color zone & 11 & 1 & Sp 1963 & 26 \\
\hline Lavender-dyed jadeite & With pink UV fluorescence and a dye spectrum & 11 & 3 & F 1963 & 82 \\
\hline Surface-treated amber & Painted surface areas lacked expected UV fluorescence & 11 & 3 & F 1963 & 87 \\
\hline Rare cat's-eyes & Pink scapolite and green chrome diopside & 11 & 4 & W 1963-1964 & 104 \\
\hline Treated jadeite bead necklace & Dyed and plastic coated with incorrect measured R.I. value & 11 & 6 & Su 1964 & 182 \\
\hline Emeralds from Brazil & Not colored by chromium; name based on color appearance & 11 & 8 & W 1964-1965 & 244 \\
\hline Famous diamond & $43.38 \mathrm{ct}$ Nassak diamond submitted for examination & 11 & 8 & W 1964-1965 & 245 \\
\hline Pink conch pearl & Description of appearance & 11 & 9 & Sp 1965 & 270 \\
\hline Cyclotron-irradiated green diamond & Umbrella effect color zoning as evidence of treatment & 12 & 3 & F 1966 & 72 \\
\hline Blue zoisite crystals (tanzanite) & First gemological description & 12 & 7 & F 1967 & 201-204 \\
\hline Tanzanian garnets & Variety of orange-brown almandine-pyrope garnets & 13 & 1 & Sp 1969 & $15-16$ \\
\hline Treated turquoise & Plastic impregnated and dyed to improve appearance & 13 & 4 & W 1969-1970 & 118 \\
\hline Laser drilling of diamonds & First description of tapering channel to bleach dark inclusion & 13 & 7 & F 1970 & 224-226 \\
\hline Treated pink diamonds & Description of distinctive properties & 13 & 12 & W 1971-1972 & 380 \\
\hline Maxixe blue beryl & Report on the material and its absorption spectrum & 14 & 4 & W 1972-1973 & $111-112$ \\
\hline Gilson synthetic opal & Description of material & 14 & 6 & Su 1973 & $175-177$ \\
\hline Yellow conch pearl & Examination of a rare-color conch pearl & 14 & 8 & W 1973-1974 & 235 \\
\hline Taaffeite & Large grayish violet cut stone & 14 & 10 & Su 1974 & $298-299$ \\
\hline Cubic zirconia & Characterization of a new diamond imitation & 15 & 5 & Sp 1976 & $154-155$ \\
\hline Cultured black pearls & Description of natural-color cultured black pearls from Tahiti & 15 & 12 & W 1977-1978 & 365 \\
\hline Diffusion-treated blue sapphires & Report on surface-related color treatment & 18 & 3 & F 1982 & 173 \\
\hline Dyed black cultured pearls & Description of distinctive properties & 26 & 4 & W 1990 & $286-297$ \\
\hline Diffusion-treated blue star sapphire & Description of color and asterism produced by diffusion & 27 & 1 & Sp 1991 & $44-45$ \\
\hline Fancy-color diamonds & Note on characteristic inclusions & 30 & 1 & Sp 1994 & $41-42$ \\
\hline
\end{tabular}

"This column began as an article titled "New and unusual gem materials encountered in the Institute's Gem Trade Laboratories" in the Summer 1957 issue of Gems \& Gemology (Nol. 9, No. 2). It then appeared under the title "Highlights at the Gem Trade Lab in New York" beginning in the Winter 1958-1959 issue Nol. 9, No. 8). The name was changed to "Developments and Highlights at the Gem Trade Lab in New York" (and/or Los Angeles) in the Summer 1960 issue Nol. 10, No. 2). It was changed again to "Developments and Highlights in GIA's Lab in New York" (and/or Los Angeles) in the Fall 1969 issue Nol. 13, No. 3). With the Spring 1981 issue Nol. 17, No. 1), it became "Gem Trade Lab Notes," and has been "Lab Notes" since the Spring 2003 issue. ${ }^{2}$ Issue abbreviations: $S p=S p r i n g$, Su=Summer, $F=$ Fall, $W=$ Winter 
black pearls for examination, and provided him with information on the culturing techniques. Following intensive study and consultation with GIA officials, the Gem Trade Laboratory decided to issue identification reports stating that the gems were naturalcolor cultured pearls. Assael recently said (pers. comm., 2003), "Thanks to this report ... the top jewelers of the world accepted this pearl as being a natural color. I owe Bob Crowningshield a great deal."

Crowningshield began investigating tissue-nucleated freshwater cultured pearls in 1962, and showed that they, too, could be identified through X-radiography (also see Benson, 1951-1952). He examined both green and lavender dyed jadeite the following year, and proved that the presence of dye concentrations in surface-reaching fractures was a definitive criterion for recognizing many stones treated in this manner (figure 10).

In the late 1960s, a sensational new gem variety of zoisite came onto the jewelry market. Tiffany \& Co. named it tanzanite after its country of origin (figure 11). Crowningshield and Richard Liddicoat published one of the first descriptive reports on this new gem material in a 1968 issue of Lapidary Journal. In 1970, Crowningshield wrote one of the first descriptions of a color-change garnet from East Africa.

At about that time, he began developing a rela-

Figure 8. From its beginning, pearl testing has been a major function of the GIA laboratory. Crowningshield is shown here with the lab's "new" $X$-ray equipment (installed in late 1951), arranging a group of pearls on the photographic film cassette before exposing them to the $X$-ray beam to produce the radiograph that will determine if they are natural or cultured.

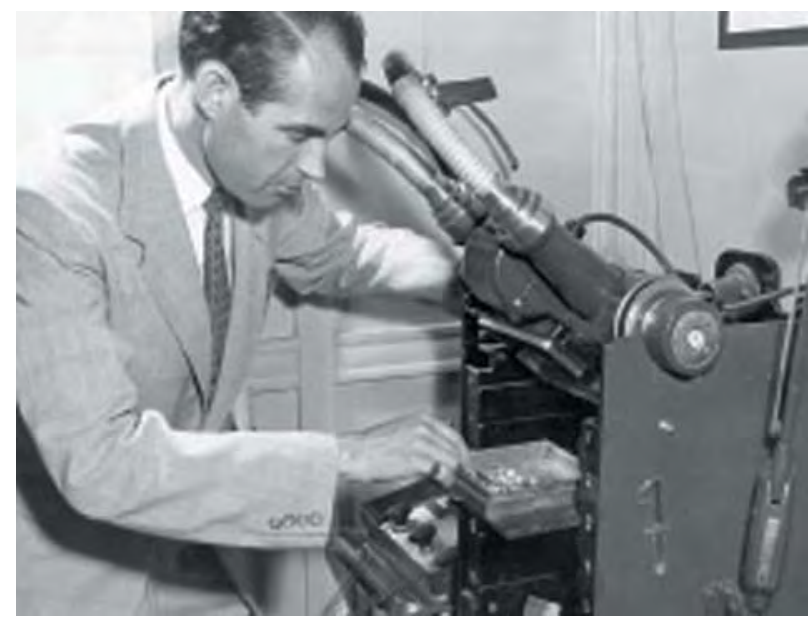

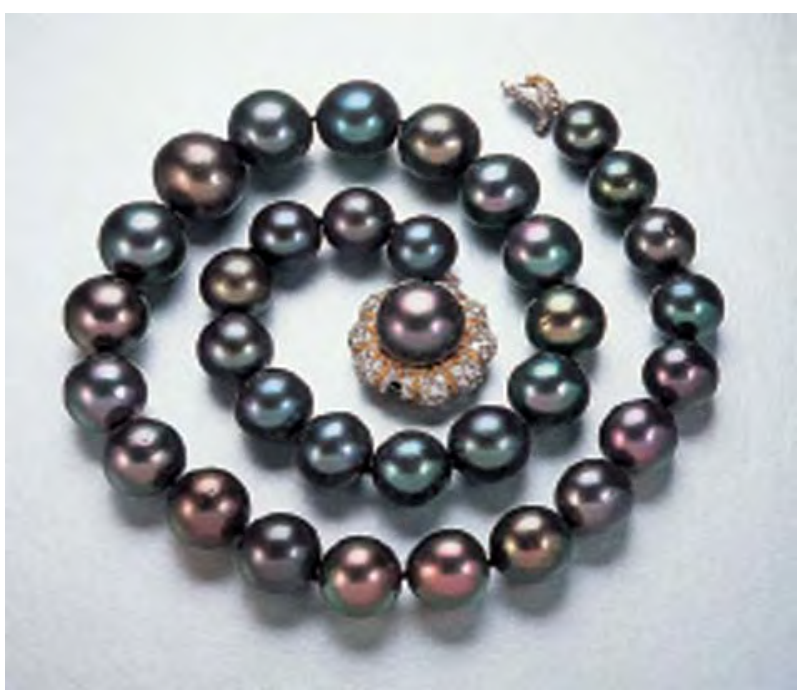

Figure 9. Largely because of Crowningshield's groundbreaking work on natural- and treated-color black pearls, jewelers were able to trade confidently in the natural-color Tahitian black cultured pearls that first entered the market in the mid-1970s. This strand of black cultured pearls (12-16 $\mathrm{mm}$ ) is courtesy of Buccellati. Photo by Robert Weldon, (C) GIA.

tionship with Dr. Kurt Nassau, a well-known scientist at Bell Laboratories in Murray Hill, New Jersey, who had an interest in gem materials. Late in 1972, the laboratory staff was shown some dark blue beryl that Crowningshield and Nassau were able to confirm as having the same properties as the so-called Maxixe beryl, a material first found in 1917 in Brazil that faded on exposure to sunlight (also see Nassau and Wood, 1973). Nassau later recalled that Crowningshield drew the spectrum of this material so precisely that the many fine lines

Figure 10. As Crowningshield reported more than 40 years ago, color concentrations in the surface-reaching cracks of jadeite jade are proof that the piece has been dyed. Photomicrograph by John I. Koivula; magnified $5 \times$. 
ment in natural and synthetic sapphires.

Of continuing importance, however, was the characterization of natural stones. In a comprehensive Spring 1983 Gems ↔ Gemology article, he described the color appearance of-and proper nomenclature for-orangy pink to pinkish orange "padparadscha" sapphires (figure 15). This article is still considered by many to be the best explanation of the color of this rare natural corundum.

Crowningshield also spearheaded a 1986 article, with Dr. Cornelius Hurlbut and C. W. (Chuck) Fryer, that discussed the separation of natural from synthetic amethyst on the basis of the presence of Brazil-law twinning in the former (figure 16). While this criterion has been subverted by the availability of twinned synthetic amethyst, at the time it offered a practical means for gemologists to identify this important colored stone. Crowningshield was very concerned about the impact on the trade of natural and synthetic stones being mixed together in a single parcel without a clear-cut method to separate them.

Figure 14. In a Summer 1971 Gems \& Gemology article, Crowningshield provided the first gemological description of the new GE jewelry-quality synthetic diamonds.

\section{GENERAL BLECTRIC'S CUTTABLE SYNTHETIC DIAMONDS}

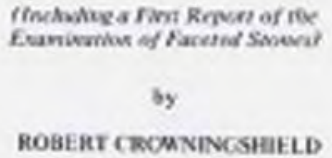

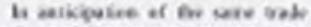
ase pablic reactios to the zesencerneat lan year fea Ceacal Bectic bad racoended in prodndy

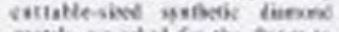
apuds we aded be the dasce to axime the fivi desox cue forn then ayulk mor to ter prestatios of a relection it tae Sraitsmonian Intresken in Nolvepin DC:

The 81 aend on if case

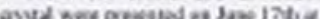

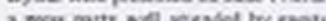

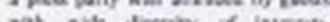
Drued the pred aflioss of $\mathrm{Dr}$. Radxs, E. Hixnorin Maniact of $\mathrm{ns}$ levoric and 3toxteno Benct of $6 \mathrm{se}$

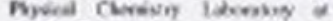
GES Revare ind Drubonaw Ceene, SClursiady, Xow Yerk, for nnes No atte to iperd a fasivale

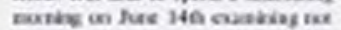
ealy the tros woes os be pres to

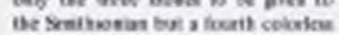
evil betien ind xerel ans crystik. For wekiven rescen

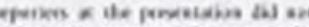

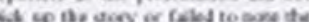

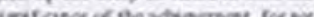
ure seand of top ocos

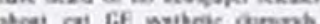
Seet col be subese ammk Rerbos $a b$ b yo ondil a far as to

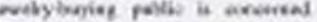
Te kovery inak perm, of esene.

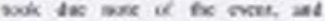
srtich to srpor o br fomim?

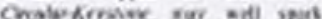

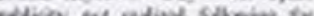

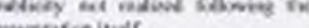

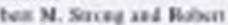
It. "Ectsat, $t$, sto an responitk lor the dcocbrinar. of the tedeigaxi

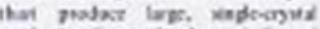

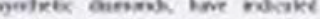

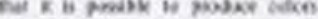

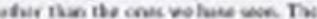

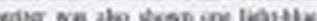

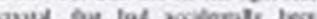

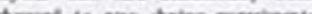
aeth

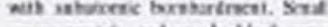
pees aysas and manty Bach exs?

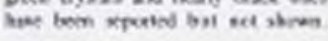

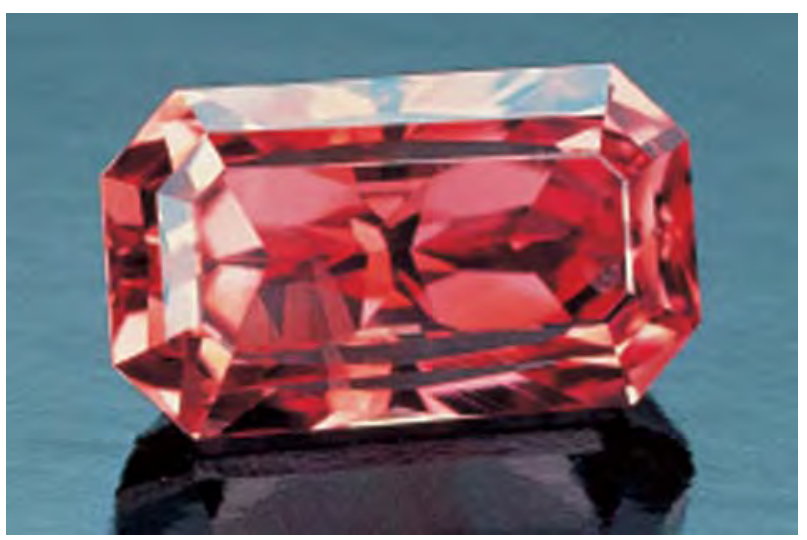

Figure 15. Crowningshield was passionate about the rare "padparadscha" sapphire, such as this 3.13 ct stone from Montana, and his 1983 article is a classic on the origin of this trade name and the definition of the color. Courtesy of M. Bielenberg; photo (C) GIA and Tino Hammid.

On occasion, Crowningshield was called on to examine gem materials of particular historic interest. In 1989, he described the quality grading of the 45.52 ct Hope diamond by members of the GIA laboratory staff, who were given a special opportunity to examine this famous gemstone at the Smithsonian Institution in Washington, DC. In the early 1990s, gem dealer Benjamin Zucker proposed to William Voelkle, the head of the Morgan Library in New York, that someone conduct a gemological examination of its early medieval Weingarten and Lindau Gospels, which were "illuminated" (hand-illustrated) manuscripts with gem-encrusted covers (figure 17). Although the manuscripts themselves had been stud-

Figure 16. This image from a 1986 report by Crowningshield, Hurlbut, and Fryer clearly shows the difference between the twinned natural (oval) and untwinned synthetic (emerald cut) amethyst then available in the trade. Photo by David Hargett.

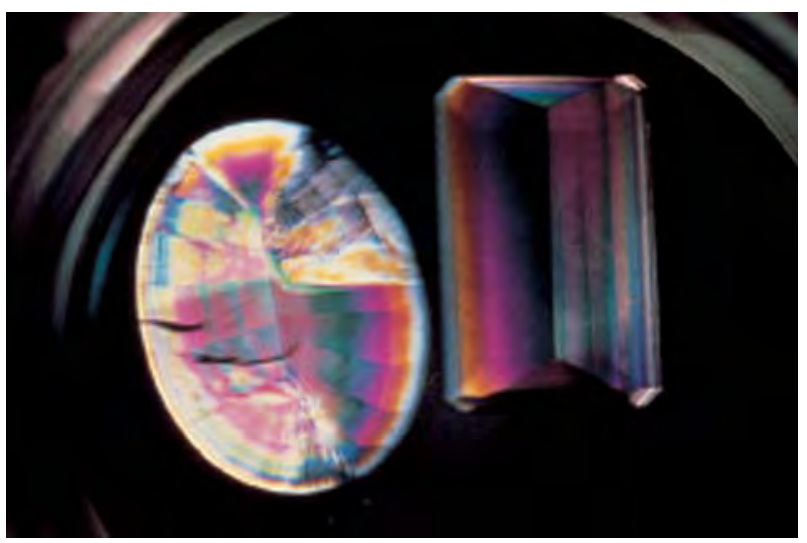



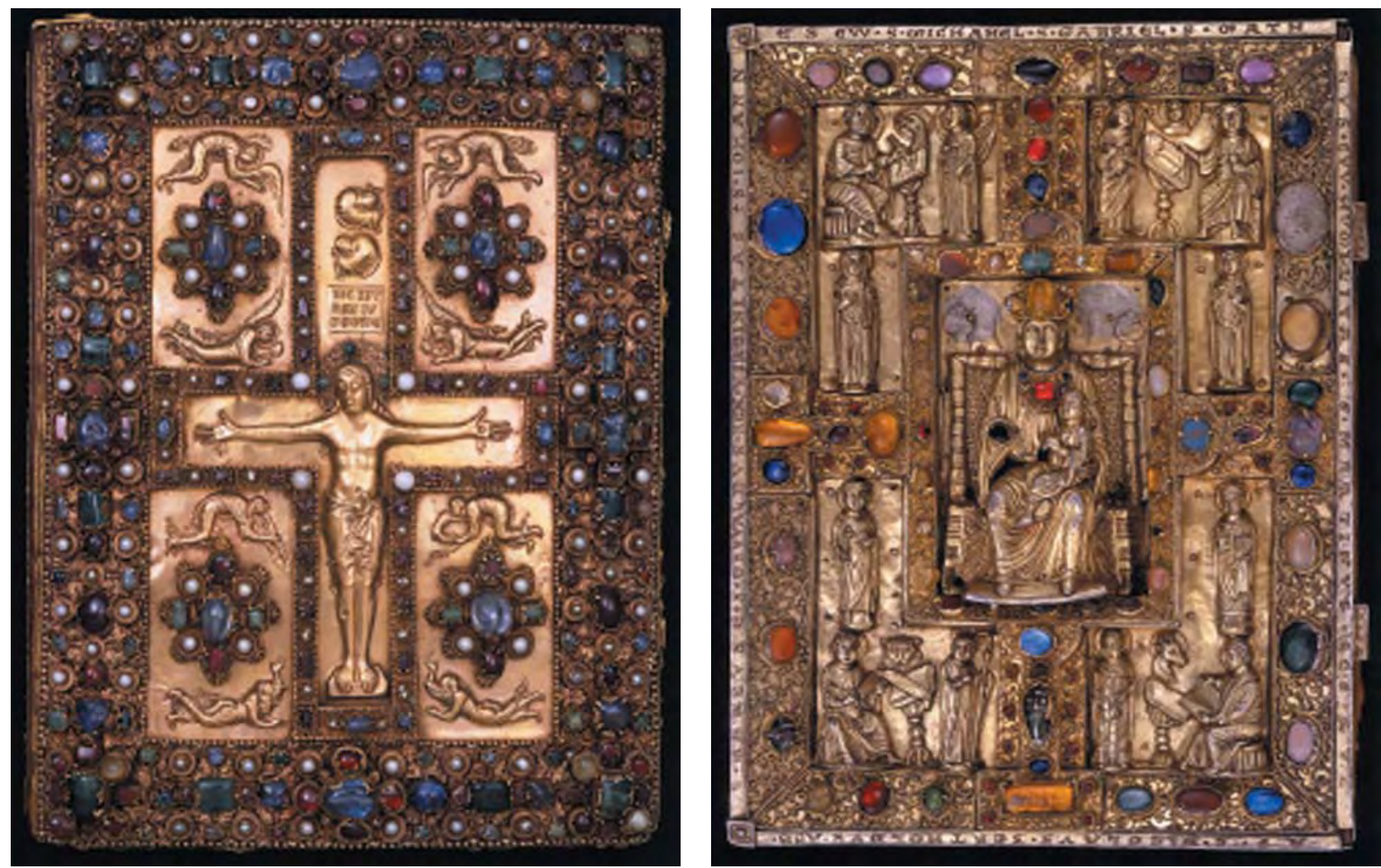

Figure 17. Crowningshield was one of three gemologists asked to identify the gemstones on the covers of the medieval Weingarten (left) and Lindau Gospels. Courtesy of the Pierpont Morgan Library/Art Resource NY.

ied extensively, the gems on the covers had never been identified or authenticated. Voelkle immediately invited GIA to conduct the examination. Over the course of five or six visits to the Morgan Library, Crowningshield, Zucker, and one of the present authors (TM) examined the book covers. The challenge was handling the rather large manuscripts and the hand-wrought gold covers, into which the stones had been set with finely made bezels. They had to take the instruments to the stones rather than vice versa. To get a refractive index, for example, they placed the refractometer upside down on the stone and used mirrors to take the readings (employing some of the methods that Crowningshield had outlined in his 1949 article). Ultimately, they were able to conclude that all of the stones-primarily rubies and sapphires, with some amethysts, citrines, chalcedonies, and garnets-were natural. As Zucker recalled in a 2003 interview:

Here was the best of all worlds: a great religious gospel, the stones embedded in this medieval book cover, the finest example of 12 th century goldsmithing, and Bob Crowningshield looking at this stone and saying: "Tom [Moses], look at this. Isn't this interesting? Look at that inclusion.
This came from Ceylon." And here are these gemstones that had come in the 12th century from Ceylon by boat or across the land route through Alexandria to Western Europe and then were set in this medieval book cover. ... I would say millennia came together in this very room.

Notes from the Laboratory. Many of Crowningshield's most notable contributions arrived in the form of short reports published in what is now the Lab Notes section of Gems ef Gemology. One of the journal's most enduring and popular features, where unusual and interesting gem materials are briefly described, was inaugurated by Crowningshield with a $1957 G \uplus G$ article titled "New or Unusual Gem Materials Encountered in the Institute's Gem Trade Laboratories."

"One of the many joys of being associated with the Laboratories of the Gemological Institute of America," he said in his 1957 introduction, "is identifying unexpected gem materials that may heretofore not have been widely reported, if at all." Over the next four decades, he wrote more than 1,000 entries on gem materials of all kinds (again, see table 1). These entries typically included why a 
particular gem material was of interest at the time, its distinctive gemological properties, and what steps were required for its identification. In reviewing these Lab Notes, one is amazed at the variety of gem identification dilemmas Crowningshield and his colleagues-such as Richard Liddicoat, Lester Benson, and Chuck Fryer-faced. It is also surprising to realize that Crowningshield was one of the first to successfully address many of these challenges-often before they became more serious problems in the trade-and that his gem-testing work frequently preceded that of others.

In addition to his many contributions to Gems e) Gemology, Crowningshield also wrote regular columns in The Loupe from the late 1940s through 1958, titled variously "Overheard in Manhattan," "Overheard in the G.I.A. Lab," and "Through the Lens at the Gem Trade Lab in New York."

\section{CO-DEVELOPER OF THE DIAMOND GRADING SYSTEM}

During the early 1950s, Crowningshield was deeply involved with Richard Liddicoat, Bert Krashes, and others at GIA in the development of a quality-grading system for polished diamonds. Prior to that time, there were many systems and terminologies being used within the trade to describe the qualities of diamonds, most of which were inconsistent and unscientific. Beginning in the 1930s, experts at GIA worked to develop effective grading procedures, equipment such as the DiamondLite (this was initially called the Diamolite), the Diamondscope, the Gemolite (see, e.g., "New diamond grading equipment," 1937; Shipley and Liddicoat, 1941; Wiss, 1946; Collison, 1947), an electronic colorimeter for measuring diamond color (Shipley, 1958), reference standards (diamond "master stones"), and a formal system of nomenclature to describe the color and clarity of diamonds that were colorless to light yellow.

Not only did Crowningshield help develop what would come to be known as the GIA Diamond Grading System, but in the spring of 1953, and through one-week traveling classes beginning in 1955, he helped teach the first GIA education courses ("Diamond Grading and Evaluation") on this system (figure 18). As journalist and GIA historian Bill Shuster reflected half a century later (pers. comm., 2003):

Just with the traveling classrooms alone, Crowningshield, Krashes, and the other GIA pio- neers helped establish the diamond grading system with jewelers across America by taking it directly to them. This is what really helped stabilize and make the system important. Because they [the jewelers] could see right there, sitting in some little town near Atlanta, Georgia, or some hamlet up in Canada near Toronto, what the gem experts were talking about.

Although the system was initially intended simply as an evaluation procedure for use by GIA students and graduates, within a short time students and members of the trade were asking the GIA instructors to help grade their diamonds in order to provide an independent assessment of the quality. As Bert Krashes-who retired as a vice president of the laboratory in 1987-recalled:

\begin{abstract}
When students returned home and graded their own diamonds, they frequently encountered challenging grading situations. As part of our service to them, we agreed to check their findings. We used diagrams of the various cuts of diamonds, on which we noted the position of inclusions as well as our grading of the stone. After word of our grading system attained some notoriety, we were asked to produce a more formal report, and that is how our diamond grading report was born.
\end{abstract}

The first formal GIA diamond grading reports were issued in 1955. Because of Crowningshield's

Figure 18. In the 1950s, Crowningshield was one of the original instructors in GIA's traveling classes to teach the Institute's new diamond grading system. Crowningshield is shown here with a September 1957 class in Indianapolis, Indiana.

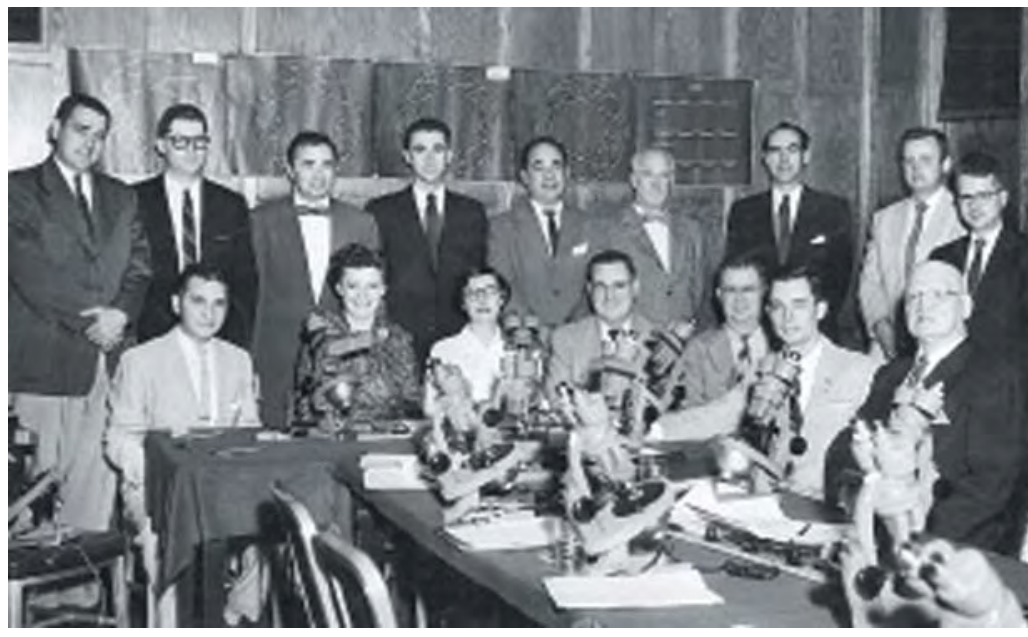




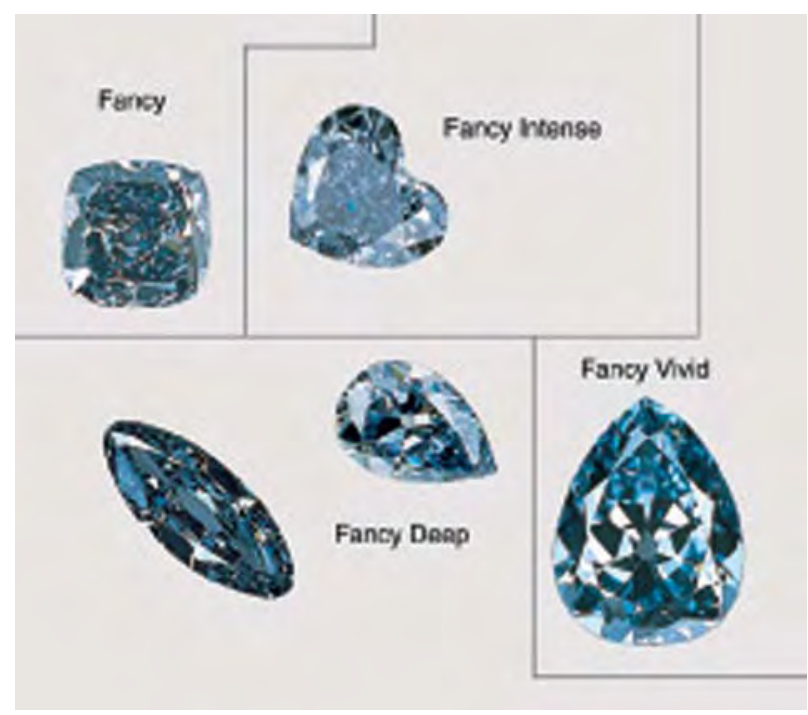

Figure 19. Crowningshield was an important contributor to the color grading system for colored diamonds. Reproduced here is a section of the color grid for Fancy blue diamonds (King et al., 1998).

prominence in teaching the system, he was regarded as one of its foremost practitioners (Federman, 1995). Even so, trade acceptance of the system took years of effort by Crowningshield and others, with dealers and jewelers only gradually recognizing its benefits. As Bert Krashes explained, "Little by little, jewelers both here and abroad found that our reports helped them sell diamonds. At first, Bob and I would each grade a diamond independently, then compare our findings. Eventually, this led to the establishment of the repeatable parameters we subsequently used in grading."

As the reports became more important, GIA sometimes encountered dealers who were unhappy with the grades their diamonds received - and were not shy about telling Crowningshield and Krashes what they thought. In a 2003 interview, diamond dealer William Goldberg commented, "Even way back then, I remember that Bob said 'No matter what-we're friends. You're a good guy, but [the diamond's grade] is what it is, and we're not going to change it because we play tennis together or have known each other for 30 years.' To me, that [integrity] is very crucial. If I had a certificate, and Bob Crowningshield's or Bert Krashes' names were on it, that always represented to me the essence of what GIA is all about."

Crowningshield was also directly involved in establishing and refining the system of color terminology that Gem Trade Laboratory staff used to describe colored diamonds. The appearance of treatedcolor diamonds in the 1950s helped create greater interest in natural-color diamonds. In addition to seeking origin-of-color reports, clients also brought in yellow diamonds to see if they were an unusual category referred to as "canaries." This required the development of procedures to visually assess diamond coloration, as well as references to mark color description boundaries. From the very beginning, Crowningshield was involved with establishing the boundary between the $\mathrm{Z}$ color grade (light yellow) and the Fancy yellow category, working with other GIA staff members as well as prominent colored diamond dealers of that era, such as Arthur Reik and Sidney DeYoung. Later refinements to this nomenclature system (see King et al., 1994, 1998, 2002) included concepts that had been developed decades earlier by Crowningshield and his colleagues (figure 19).

\section{ALWAYS THE EDUCATOR}

Crowningshield was involved in teaching gemology to Institute students and other members of the jewelry trade from his first weeks at GIA. Over a period of 42 years starting in 1951, he was also a popular speaker at the annual educational meetings of the American Gem Society (figures 20 and 21); see the Gems et Gemology data depository for a list of his presentations and other contributions at these AGS Conclaves [http://www.gia.edu/gemsandgemology, click on "GetG Data Depository"]. Written ver-

Figure 20. For more than four decades, Bob Crowningshield was a popular speaker at the annual AGS Conclaves.

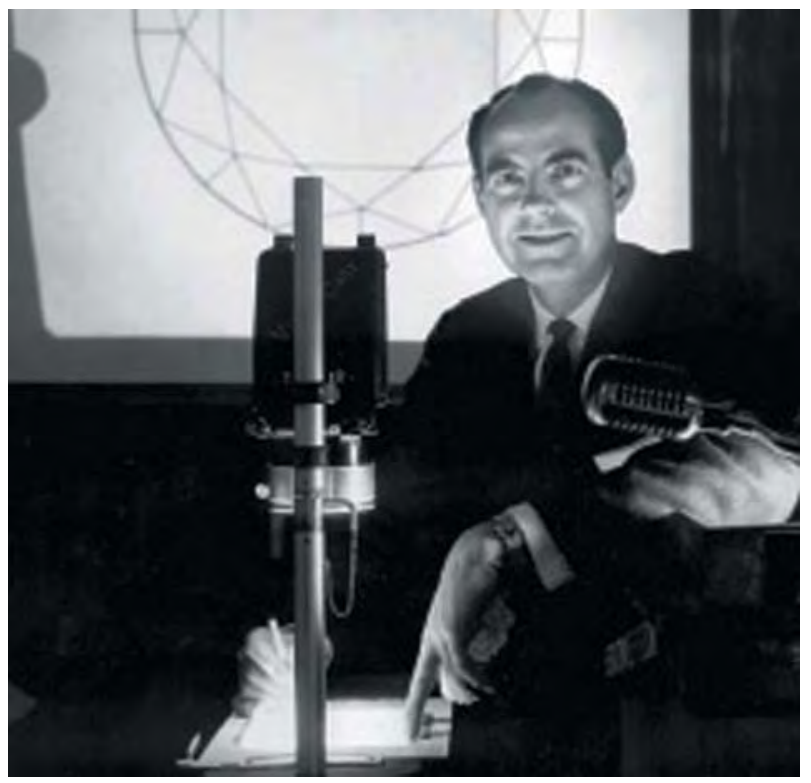


sions of the majority of these presentations can be found in the AGS Guilds magazine. Crowningshield also presented at several of the biannual International Gemmological Conferences as well as to other industry groups, such as GIA Alumni and trade associations.

In addition to his gemological reports, Crowningshield published many notable articles on general subjects of interest to the trade. In a two-part 1953 piece, he discussed several principles for the marketing of colored stone jewelry as accessories to current fashions. He wrote about a practical procedure, published in 1958 both in Gems \&) Gemology and the Journal of Gemmology, for documenting the extent of physical damage or inherent flaws in polished gemstones. This article arose from the work done by laboratory staff to ascertain damage to client gems, often in cases involving insurance claims. A 1963 article that described the care of gem materials during the manufacture, repair, display, and wearing of jewelry was also based on his examination of damaged gems that had been submitted to the lab.

An important teaching point in GIA education classes is for students to learn the correct definitions and usage of a number of gemological terms. In 1960, Crowningshield coauthored the first edition of the GIA Diamond Dictionary, which provided these gemological terms when no other suitable dictionary was available. Crowningshield's last published article appeared in 1995, a study on separating natural from treated pink diamonds that he wrote with several GIA colleagues for Diamond World Review.

Crowningshield's outreach also included the general public, with interviews about gems and jewelry on radio in the 1950s (figure 22) and television programs such as the RCA Jewelry Show in 1964.

\section{PROFESSIONAL RECOGNITION}

During his long career, Bob Crowningshield has been the recipient of a number of professional recognitions. A Certified Gemologist of the American Gem Society since 1948, in 1983 he was awarded AGS's Robert M. Shipley Award for outstanding service to the jewelry industry. In 1991, GIA established the G. Robert Crowningshield Gemological Research Laboratory as the Institute's focal point for research work on gem identification. In 1995, he received the 12th annual Lifetime Achievement Award from Modern Jeweler magazine. Crowningshield is an honorary director of the Canadian Gemmological Association and a recipient of the Accredited Gemologists Association's

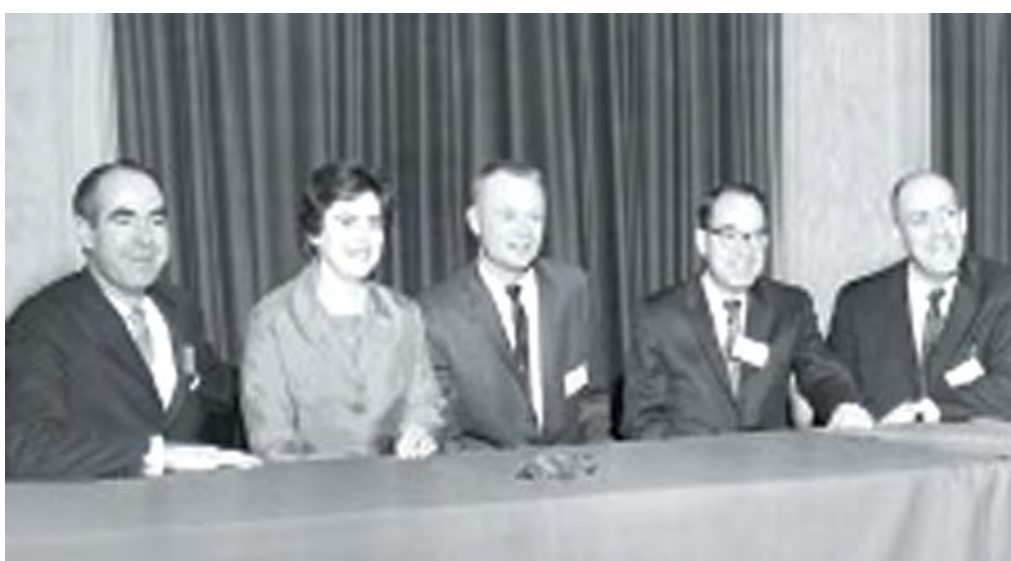

Figure 21. Bob Crowningshield, Eunice Miles, Glenn Nord, Richard Liddicoat, and Bert Krashes participate in a gemological panel at the 1965 AGS Conclave in Chicago. Each of these individuals played a key role in educating the industry.

Antonio C. Bonnano Award for Excellence in Gemology. Most recently, this year he was honored with the AGS Lifetime Achievement Award (figure 23) and was inducted into GIA's League of Honor.

In a 1995 article describing the Lifetime Achievement Award from Modern Jeweler, David Federman explained why Crowningshield was so well respected throughout the industry and the research community:

As the Sufi mystics say, "Duty is greater than God." And Crowningshield is the rare exemplar of that aphorism. No wonder he is among the most revered teachers and practitioners of gemology in the post-war era. And because of his legendary dedication to his profession, he has

Figure 22. Because of his gemological expertise, Bob Crowningshield was often asked to speak to the public about gems, as in this NBC radio interview in the 1950s.

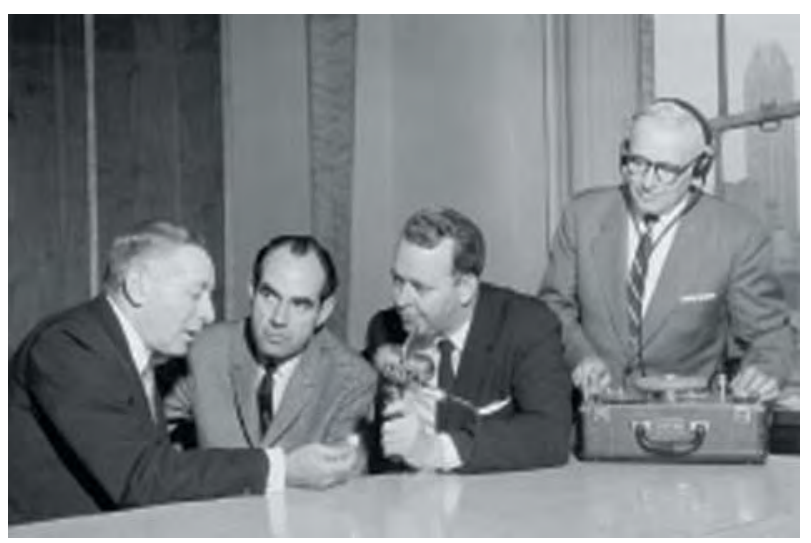




\section{CHRONOLOGICAL BIBLIOGRAPHY}

Crowningshield G.R. (1949) Additional notes on refractive indices of cabochon cut stones. Gems e) Gemology, Vol. 6, No. 6, pp. 176-177.

Crowningshield G.R., Holmes R.J. (1950-1951) Synthetic red spinel. Gems «) Gemology, Vol. 6, No. 12, pp. 362-368.

Crowningshield G.R., Ellison J.G. (1951) The determination of important optical properties without instruments. Gems «) Gemology, Vol. 7, No. 4, pp. 120-124

Crowningshield G.R. (1953) Costuming and the sale of colored stone jewelry (Part 1). Gems \&) Gemology, Vol. 7, No. 10, pp. 307-309, 313; (Part 2) Gems e) Gemology, Vol. 7, No. 11, pp. 335-338, 351.

Liddicoat R.T., Crowningshield G.R. (1955) Strontium titanate. Gems (4) Gemology, Vol. 8, No. 5, pp. 148, 156.

Crowningshield G.R. (1957) New or unusual gem materials encountered in the Institute's Gem Trade Laboratories. Gems et Gemology, Vol. 9, No. 2, pp. 35-37, 61-62 (the article that began the Lab Notes series in the following year [initially entitled "Highlights at the Gem Trade Lab ..."]).

Crowningshield G.R. (1957) An introduction to spectroscopy in gem testing. Gems «) Gemology, Vol. 9, No. 2, pp. 46-55, 62.

Crowningshield G.R. (1957-1958) Spectroscopic recognition of yellow bombarded diamonds and bibliography of diamond treatment. Gems e) Gemology, Vol. 9, No. 4, pp. 99-104, 117.

Crowningshield G.R. (1958) Ascertaining the nature and extent of damage or inherent flaws in gemstones. Gems et Gemology, Vol. 9, No. 5, pp. 131-133, 159 (reprinted in Journal of Gemmology, Vol. 6, No. 8, pp. 355-359, 1958).

Copeland L.L., Liddicoat R.T. Jr., Benson L.B. Jr., Martin J.G.M., Crowningshield G.R. (1960) The Diamond Dictionary, Gemological Institute of America, Los Angeles, 317 pp.

Holmes R.J., Crowningshield G.R. (1960) A new emerald substitute. Gems «) Gemology, Vol. 10, No. 1, pp. 11-22.

Crowningshield G.R. (1961-1962) The spectroscopic recognition of natural black pearls. Gems Æ Gemology, Vol. 10, No. 8, pp. 252-255.

Crowningshield G.R. (1962) Fresh-water cultured pearls. Gems et Gemology, Vol. 10, No. 9, pp. 259-273.

Crowningshield G.R. (1963) Care of gem materials and their substitutes in manufacturing, repairing, displaying and wearing of jewelry. Gems e) Gemology, Vol. 11, No. 1, pp. 3-11.

Liddicoat R.T. Jr., Crowningshield G.R. (1968) More about zoisite, a new gem sensation. Lapidary Journal, Vol. 22, No. 6, pp. 736, 740.

Nassau K., Crowningshield G.R. (1969) The synthesis of ruby. Part One: The Nineteenth Century, Verneuil, and the mystery of "reconstructed" ruby. Lapidary Journal, Vol. 23, No. 1, pp. 114, $116-119$

- (1969) The synthesis of ruby. Part Two: The mystery of "reconstructed" ruby solved. Lapidary Journal, Vol. 23, No. 2, pp. 313-314, 334-338.

(1969) The synthesis of ruby. Part Three: The mystery of "reconstructed" ruby solved. Lapidary Journal, Vol. 23, No. 3, pp. 440-446.

- (1969) The synthesis of ruby. Part Four: Supplementary note on "Geneva" ruby. Lapidary Journal, Vol. 23, No. 4, p. 621

Crowningshield G.R. (1970) World's largest phenakite. Gems $\oplus$ Gemology, Vol. 13, No. 6, pp. 178-181.

Crowningshield G.R. (1970) Diamonair: A new diamond substitute. Lapidary Journal, Vol. 23, No. 12, pp. 1614, 1616-1619.

Crowningshield G.R. (1970) A rare alexandrite garnet from Tanzania. Gems et) Gemology, Vol. 13, No. 6, pp. 174-177.

Crowningshield G.R. (1970) Several simple tests can identify manmade diamonds, says GIA. Jewelers' Circular-Keystone, Vol. 140 No. 11, pp. 188-189 (reprinted in Australian Gemmologist, Vol. 10, No. 12, pp. 7-9).

Crowningshield G.R. (1971) General Electric's cuttable synthetic diamonds. Gems e) Gemology, Vol. 13, No. 10, pp. 302-314.

Crowningshield G.R. (1971) America's largest faceted emerald. Lapidary Journal, Vol. 25, No. 1, pp. 40, 42.

Crowningshield G.R. (1981) Irradiated topaz and radioactivity. Gems (4) Gemology, Vol. 17, No. 4, pp. 215-217.

Crowningshield G.R., Nassau K. (1981) The heat and diffusion treat- ment of natural and synthetic sapphires. Journal of Gemmology, Vol. 17, No. 8, pp. 528-541.

Crowningshield G.R. (1982) Cultured 3/4 blister pearls. Gems Æ) Gemology, Vol. 18, No. 1, pp. 36-38.

Crowningshield G.R. (1982) The GIA and the colored stone trade. In D.M. Eash, Ed., International Gemological Symposium Proceedings, Los Angeles, February 12-15, Gemological Institute of America, Santa Monica, CA, pp. 29-30.

Crowningshield G.R., Nassau K. (1982) The heat diffusion treatment of natural and synthetic sapphires. In D.M. Eash, Ed., International Gemological Symposium Proceedings, Los Angeles, February 12-15, Gemological Institute of America, Santa Monica, CA, pp. 101-109.

Crowningshield G.R. (1983) Padparadscha: What's in a name? Gems (4) Gemology, Vol. 19, No. 1, pp. 30-36.

Crowningshield G.R., Hurlbut C., Fryer C.W. (1986) A simple procedure to separate natural from synthetic amethyst on the basis of twinning. Gems e) Gemology, Vol. 22, No. 3, pp. 130-139.

Crowningshield G.R. (1989) Grading the Hope diamond. Gems ef Gemology, Vol. 25, No. 2, pp. 91-94.

Crowningshield G.R. (1991) Colored stones: Identification and quality analysis. Panel presentation, in A.S. Keller, Ed., Proceedings of the International Gemological Symposium 1991, Los Angeles, June 20-24, Gemological Institute of America, Santa Monica, CA, pp. $124-125$.

Kammerling R.C., Crowningshield R., Reinitz I., Fritsch E. (1995) Separating natural pinks from their treated counterparts. Diamond World Review, No. 88, pp. 86-89.

\section{REFERENCES}

Benson L.B. (1948) Refractive indices of cabochon cut stones. Gems (4) Gemology, Vol. 6, No. 2, pp. 35-37, 58.

Benson L.B. (1951-1952) Gem Trade Laboratory installs new pearl testing equipment. Gems «) Gemology, Vol. 7, No. 4, pp. 107-112.

Benson L.B. Jr. (1960) Testing black pearls. Gems Æ) Gemology, Vol. 10 , No. 2, pp. 53-58.

Collison W. (1947) The new standard Diamolite. Gems «) Gemology, Vol. 10, No. 7, p. 431.

Federman D. (1995) Lifetime achievement award: Robert Crowningshield. Modern Jeweler, Vol. 94, No. 12, pp. 25-32.

Hodgkinson A.H. (1995) Visual Optics, the Hodgkinson Method. Gemworld International, Northbrook, IL, 50 pp.

King J.M., Moses T.M., Shigley J.E., Liu Y. (1994) Color grading of colored diamonds in the GIA Gem Trade Laboratory. Gems Gemology, Vol. 30, No. 4, pp. 220-242.

King J.M., Moses T.M., Shigley J.E., Welbourn C.M., Lawson S.C., Cooper M. (1998) Characterizing natural-color type IIb blue diamonds. Gems e) Gemology, Vol. 34, No. 4, pp. 246-268.

King J.M., Shigley J.E., Guhin S.S., Gelb T.H., Hall M. (2002) Characterization and grading of natural-color pink diamonds. Gems «) Gemology, Vol. 38, No. 2, pp. 128-147.

Liddicoat R.T. Jr. (1962) Handbook of Gem Identification, 6th ed. Gemological Institute of America, Los Angeles.

Nassau K., Wood D.L. (1973) Examination of Maxixe-type blue and green beryl. Gems \&) Gemology, Vol. 14, No. 5, pp. 130-133.

New diamond grading equipment (1937) Gems e) Gemology, Vol. 2, No. 7, pp. 114-118.

The new Eastern headquarters and Gem Trade Lab of GIA (1960) Gems et) Gemology, Vol. 10, No. 2, pp. 35-44, 63.

Pough F.H., Schukle A.A. (1951) The recognition of surface irradiated diamonds. Gems et) Gemology, Vol. 7, No. 1, pp. 3-11.

Radium-treated diamonds (1938-1939) Gems Æ) Gemology, Vol. 2, No. 12, p. 194

Shipley R.M., Liddicoat R.T. (1941) A solution to diamond color grading problems. Gems e) Gemology, Vol. 3, No. 11, pp. 162-168.

Shipley R.M. Jr. (1958) An electronic colorimeter for diamonds. Gems (4) Gemology, Vol. 9, No. 5, pp. 136-142, 158.

Shuster W.G. (2003) Legacy of Leadership: A History of the Gemological Institute of America. Gemological Institute of America, Carlsbad, CA.

Wiss J.B. (1946) Use of the Diamondscope. Gems \&) Gemology, Vol. 5, No. 4, pp. 285-288; Vol. 5, No. 5, pp. 313-314. 